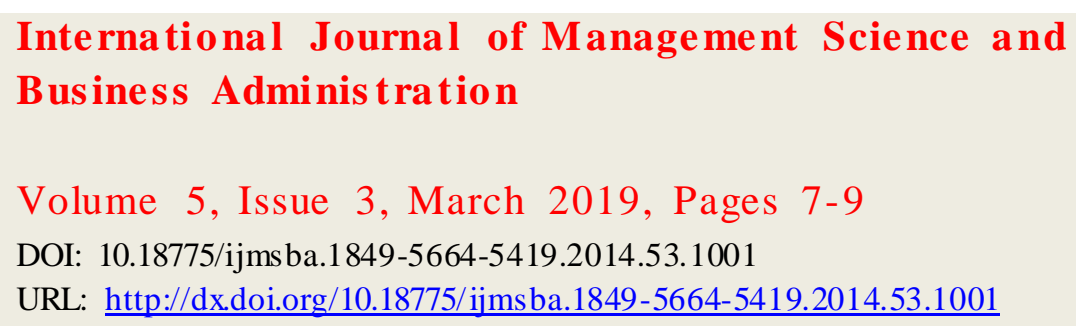

\title{
Are Women Better Leaders than Men? Gender Differences in Management Styles
}

\author{
Sylla Mamadou \\ Department of Economics and Management, Félix Houphouët-Boigny University, Abidjan, Cote d'Ivoire
}

\begin{abstract}
Management is the set of management or administrative techniques that can direct, guide, coordinate and control resources (human and material), performance within an organization to achieve one or more objective (s). Better, others think that it is the action, the art or the way of leading an organization, to direct it, to plan its development and to control it. That could lead to the concern that humankind and his half are manipulating differently. To answer this problem, we will first study the qualities of a good manager, considered as the repository. Then, we will analyze the different management styles used by men and women as well as their impact on group cohesion.
\end{abstract}

Keywords: Gender, Human, Management, Comparative Approach, Leadership

\section{Introduction}

We promise professional equality between men and women at the management level. We notice that companies are setting themselves more and more targets in terms of numbers, that is to say between $25 \%$ and $35 \%$ of women at all management levels. This situation is very positive because it is still missing today: quantitative objectives and performance indicators. However, equality of treatment is also necessary; because all the statistics show that there are still differences, especially in terms of extra-legal benefits. Today, professionalequality is mostly guaranteed by law in many countries. Companies are asked to report on their efforts in terms of gender equality in their social report. But when we look at the practical application of these principles, that is another story. So, that begs us to develop a sensitivity in the woman; which makes her stronger today as a manager. It helps her to see the performance of people, but also what is holding them back and so to encourage the talents in a different way than some of her colleagues. So, a huge empathy for all those women who dare to get up because they have in their heads, in their hearts and in their legs things to express, but also to accept the moments of weakness.

In the past, women were relegated to the background in important decisions. Nevertheless, nowadays, women become more and more important as leaders or managers. Therefore, they must use an effective management style. Management somewhere is also the influence (authority) that an individual exercises over the group or organization. There are two types of management (law or fact) and three essential styles: authoritarian, participatory and laissez-faire. Are women better managers than men? To answer this problem, we will, first of all, see how to recognize a good manager. Then we will study the different management styles used by men and women and their respective impacts on group cohesion.

\section{How to Recognize a Good Manager?}

Above all, we will study how to recognize a good manager by analyzing the characteristics of the behavior of the latter and the gender approach (men and women). What are the qualities of a good manager?

We can, first of all, notice that there is no sexism because the job of a manager is, above all, based on the skills, experience, and personality of the latter. Then a good manager must possess certain qualities.

He must be faithful to his subordinates. A good leader must, therefore, be optimistic so that his collaborators can trust him. But for that, it is necessary that the manager has him even confidence in him. Also, the group manager must be 
courageous to make major decisions for the group or organization. Finally, the manager of a group must be fair in his decision-making, for example, during a conflict. Finally, he or she must be frank with his subordinates so as not to generate rumors that could harm the cohesion of the group.

\section{The Comparative Approach between Male Management and Female Management}

Are the male and female management styles the same?

Men and women have very different personalities and ways of working. To begin with, we can say that male behavior would lie on the accomplishment of tasks, structure, power, career, higher emotional control, and a more s trategic vision of work. And we deduce that the power of men derives from their status, so they use management of law. Men are very strict, so they tend to be authoritarian and they would, therefore, be more likely than women to adopt an authoritarian style or, on the contrary, a laissez-faire style. So, they take decisions, alone without the advice of their subordinates.

However, we can notice that a female behavior would focus on the relational, the emotivity (to express his enthusiasm and his dynamism), the motivation on the part of his subordinates: work sharing and problem-solving center on instruction. The management style used by women would be participatory, which means that the power of the manager comes from his relationship with the people under his responsibility. Leaders who use a participatory approach, make decisions with the advice of their collaborators. Thus, women use a management style of fact, so their power comes from their personality. Then we will study the impacts of male and female leadership on the group.

\section{The Impact of Management Style Men and Women}

\subsection{Impact of Men's Leadership on Group Cohesion}

Previously, we have seen that most male managers tend to use an authoritarian style. Men use a management style of law. The leader's power derives from his status, his hierarchical position. He makes decisions alone and does not seek the advice of his subordinates. This style of management is directive with its teams; it promotes risk-taking but also the retention of information and strategic thinking. Unfortunately, this style has some disadvantages. First, the leader can ask the maximum or even the impossible from the persons underhim, which can lead to stress, so that the work can be done poorly. Then, all his time is hogged to solve the problems of the present or to make up for the mistakes of the past. He no longer has the time to plan for the future or to plan; this often goes against the management planning function.

\subsection{Impact of Women's Leadership on Group Cohesion}

Earlier, we noticed that women, in general, used a participative style and therefore worked with their subordinates and made decisions by asking their opinions. This method is de facto management and the power of the one who applies it derives from his personality. This style of management promotes the feeling of fulfillment in the individual. The beginning is to create working conditions favoring communication, and the cost of participative management also implies the delegation of power. In effect, involving means sharing the responsibilities of management in the different levels of the organization. Only, it is essential that subordinates have confidence in their manager and vice vers a for the power to be shared. All these characteristics make it possible to put a good atmosphere within the group and allow the subordinates to blossom.

\subsection{Why Do Women Manage Better Than Men Do?}

In the magazine Paris, published on September 7, 2015, Diana Rillet states that in the battle of the genders, recent studies have shown that women are better leaders than men who still occupy the majority of positions. A US consulting firm, "Zenger \& Folkman", conducted a study on leadership and found that women ranked better in twelve characteristics of the sixteen studied among more than seven thousand leaders. According to this magazine, they communicate better than men, and this is the most decisive competence in the management of employees. Listening or communication are necessary skills because the employees want a manager who pays attention to their ideas and point of view. As for the customers, they are sensitive to the empathy manifested toward their problems. Being an excellent communicator generates a strong relationship based on trust which is essential as it will bring faithfulness. Women build communities because they know how to develop a successfulcooperative relationship better than the one who gives orders . 
Women are more respectful of business ethics: they manage more effectively because they recognize and consider the rights of others, and want to respect a form of equity that they apply in a non-arbitrary manner. Moreover, the woman would more often apply a kind of strong moral code that helps her when she faces challenges that could push her out of the law and norm.

Women are patient because they are very much willing to wait for a result or a change in the behavior of a collaborator. She is less likely to come to an immediate conclusion or make a quick decision or premature action. This makes them winners, and the winning manager is the one who shows patience, decides on measures that translate into small steps towards a more specific goal. Better, woman arouses the passion in the work because she would exhibit more cleverness in a way to stimulate the passion for work in her collaborators. This is yet another essential quality in terms of management because passion animates, motivates and creates loyalty.

Nonetheless, this idea or this study has its limits; it is questionable. It makes a very theoretical portrait: in fact, the woman would be more enterprising, more honest, more endowed to create a cohesion of a team, but not very strong in initiative taking, which is more recognized as a male skill. To say that she would be more honest in her management may be a common stereotype in the same way as to say that she pays better attention to others. Alternatively, even greater integrity, leaving superiority to men over the ability to develop a strategic point of view for the company.

Besides, some argue that nothing scientifically proves that a woman manages differently from a man, and it is life experiences, but not gender, that forges the character of a manager. Other critics like Mickael Hingan, in 2016, went even further to say that this article by Diana Rillet was useless. For him, the truth is that it is each individual (man or woman) with his own "human qualities", "Skills" and "experiences" that will make the much-awaited difference in the area in which he or she evolves according to his or her sensitivities. Moreover, that is because the author of this article is paradoxically a woman. Worse, there are women who manage like men and vice versa (Look for example politics is a beautiful showcase that illustrates that). Also, if we look around ourselves, we will see that there are men who develop their femininity and women their masculinity.

\section{Conclusion}

We can say that women manage differently than men because they have a de facto management while men apply management of law. It appears that they have made much progress because they are more present in major decisionmaking; which was not the case before. Also, this is due to their management style (participative) different from that of men (authoritarian, directive and often laissez-faire). Moreover, some women adopt a type of management similar to that of men. There are, of course, common characteristics that identify the leaders and that correspond to the culture of the company and the sector of activity. Denying the values of a woman manager would be reductive. Women have had to develop specific skills through corporate culture. However, do women allow better group cohesion?

\section{References}

- Brillet, F(2007), Management Personnel, Février / Mars

- Capron M., Quairel-Lanoizelée 2004, voire d'une volonté de justice

- Commission green paper 2001 "Promoting a European Framework for corporate social responsibility"

- De Kergoren, Y., 2006, organisation, la tribune du 20 octobre 2006

- Diana Rillet, Paris "Why do women manage better than men? », September 7, 2015

- Forbes Magazine: The World's Most Influential Women

- Jack, Z. and Joseph, F. (2012), Are Women Better Leaders than Men?, Havard Business Review

- Kandulla R et Fullerton J, cité par Bender AF in revue Français à de gestion, Aout 2004

- Le marketing et la performance commerciale de l'entreprise, mais également l'éthique au travers du renouveau du concept de responsabilité sociale des entreprises, Cornet 2002

- Scotto M.J et A.1., Management et Avenir, $2008 / 4$ ( $\left.\mathrm{N}^{\circ} 18\right)$ pages 18 à 41

- Mickael Hingan, (2016) Source: online htt: www.hominides.com / html / folders / brain /.phP

- Montaigne, C. (2007), ces derniers bastions masculins qui tombent. Les échos, 8 Mars

- Orse (2004), répertoire des accords d'égalité professionnelle.

- Petrovic, A (2006), Homme et expertise, la Tribune , 27 octobre 2006

- Source: www.lexpress.fr published on 30042014 at 14h 49 updated on 28052014 at $15 \mathrm{~h} 17$ (page consulted the 05032018 at 9h45) 